storytelling and dramatic action. In all, Rindzevičiūtė has provided a rare glimpse through the lens of a boutique institutional history of a time and place-in a refurbished mansion outside of Vienna-where east and west fashioned in person an analytic view so global it eventually overshadowed, at least on occasion, their own distinct worldviews. In this hopeful glimpse of the past, the book's limitations are more than matched by its multilingual strengths.

BenJAMin PETERS

University of Tulsa

\title{
Das Ukraine-Bild in Deutschland: Die Rolle der russischen Medien. Wie Russland die deutsche Öffentlichkeit beeinflusst. By Susanne Spahn. Schriften zur inter- nationalen Politik, Band 51. Hamburg: Verlag Dr. Kovač, 2016. ix, 170 pp. Notes. Bibliography. Illustrations. €79.80, paper.
}

doi: 10.1017/slr.2018.362

In what is perceived as an age of fake news, the study of media might be able to shed light upon the alleged or positive influence of the Russian state on another country's public sphere. Susanne Spahn has studied German coverage of contemporary Ukraine. She interprets state-controlled mass media as well as the internet as tools of Russian soft power extensively used to shape perceptions of eastern Europe in the west. Ukraine serves as a case in point.

Peter Pomorantsev and others have introduced the distinction between propaganda (as a twentieth century concept, meaning a "great narrative") and post-modern political influence, which does not intend to create believers but to obscure and discredit realities by creating ever new stories about a certain subject. According to Spahn, Russia's goal in the current political conflict is to discredit western mainstream media and its content and-as in Soviet times-to sow discord between the United States and western Europe. In Europe itself, Moscow aims to discredit the European Union and its institutions. Politically, Moscow supports positions of the extreme Right and the extreme Left in order to delegitimize centrist and liberal positions in the public sphere.

The main part of Spahn's work discusses different channels of influence created by the Russian government to reach out to the German public. Among these, she notes RT Deutsch, Ruptly TV, as well as RIA Novosti and Stimme Russlands as official media funded by Russia. The author also portrays the unofficial ("hybrid") agencies used to influence German social media such as "troll factories" and hackers connected to the Russian state, but also somewhat detached in order to achieve "plausible deniability" of state interference. In addition to the official and disguised media outlets of the Russian state, Spahn discusses those German news channels that she deems to cooperate with the interests of Russia and those experts who play a prominent role in both Russian and German media and who advocate positions of the Putin government. Among them she points to anti-American, antisemitic, and right-wing actors who promote positions like "Germany is an American colony" and spread a conspiratorial world view. Among the most prominent are Jürgen Elsässer, who heads the journal Compact, and Alexander Rahr, who used to work for the think-tank DGAP and is now connected to Gazprom's German partners. Gabriele Krone-Schmalz, a former journalist of Germany's public television, is a best-selling author of books who defends Russian policies and blames the conflict in Ukraine on the west. In conjunctions with politicians of the right-wing Alternative für Deutschland and the post-communist Die Linke, she may be described as one of the stars of this genre. While Spahn describes 
the various actors of the pro-Kremlin milieu in Germany she does not analyze the cultural context and the historical traditions that make these phenomena possible. The book falls short of providing an in-depth understanding of the pro-Kremlin side of the German public.

The latter part of the book documents some of the fake news campaigns targeted to the German public. Due to the focus on the Ukrainian conflict, the author highlights the misrepresentation of the Maidan Revolution and the alleged discrimination of Russian speakers in Ukraine. Additionally, she points to the one-sided representation of history-especially of the Second World War, but also of Ukraine-through the Russian media. While the book offers an overview describing the actors of proKremlin campaigns in Germany, it does not provide an in-depth understanding of German-Russian and German-Ukrainian relations which are more complex and may not be reduced to the politics of the post-Maidan conflict. Future research also needs to reassess the value of negative public relations and "fake news" for governments. In the aftermath of the American election of 2016, the whole subject has become politically loaded because of the success of Donald Trump and his connections to Russia. Still, we also need to explain the limits of Russian influence that have existed both before and during the Cold War in Europe and continue to exist today. The loss of trust in the mainstream media may be exploited by foreign powers but it is also indicative of the societies targeted.

Susanne Spahn has surveyed different ways in which the current regime in Russia seeks to influence public opinion in Germany. For a while, the Kremlin has enjoyed a certain success in misrepresenting the causes as well as the facts of the war it is waging against Ukraine. With few exceptions, such as the notorious books of Krone-Schmalz, Russian-sponsored media has remained a fringe phenomenon. They do not dominate public discourse about Ukraine. In order to gain a deeper understanding of the ways eastern Europe is represented in Germany, we need to understand the way German problems of the past and present are often projected on places like Russia and Ukraine. While Russia has a certain proficiency in exploiting these German preoccupations, it has certainly failed to fundamentally alter the perception of the German public and elites. Still, Spahn has compiled information available on Russian-sponsored media in Germany and leaves us with questions of how open societies should react to such challenges by authoritarian polities.

JAN ClaAs BeHREnds Zentrum für Zeithistorische Forschung Potsdam 